\title{
Clinical experiences of infectious scleral ulceration: a complication of pterygium operation
}

\author{
Chang-Ping Lin, Min-Hsiu Shih, Ming-Chi Tsai
}

\begin{abstract}
Aims-To report the special clinical manifestations and determine the appropriate management of infectious scleral ulceration.

Methods-A retrospective study was performed on 30 eyes with infectious scleral ulceration. Information was recorded on patients' age, onset and course of disease, pathogenic organism, clinical presentations, methods of diagnosis, treatment, and outcome.

Results-10 cases (33.3\%) were accompanied by corneal involvement. Subconjunctival abscess was noted in 16 cases $(53.3 \%)$. 17 cases $(56.7 \%)$ gave positive results of pathogen culture and all were Pseudomonas aeruginosa. Two cases had combined bacterial infections and one case was complicated by fungal infection. A total of 26 cases had surgical debridement in this series. Extensive involvement of the sclera with the presence of a 'tunnel lesion' or a 'satellite subconjunctival abscess' were found during debridement. All of the eyeballs involved were salvaged except one.

Conclusion-The results of this study were contrary to the poor prognosis presented in previous reports. Early and repetitive surgical debridement is believed to be mandatory in the intractable cases to shorten the admission period and to save these eyes.

(Br F Ophthalmol 1997;81:980-983)
\end{abstract}

Infectious scleral ulceration has not been reported commonly in the USA and Europe. Most reported infectious scleral ulcers are associated with systemic infection ${ }^{1}$ including tuberculosis ${ }^{23}$ and syphilis, ${ }^{45}$ severe infectious endophthalmitis, ${ }^{67}$ keratitis, ${ }^{8-10}$ scleral buckling surgery for retinal detachment, ${ }^{11-13}$ or unsutured small incision cataract surgery. ${ }^{14}{ }^{15}$ However, reports from the areas where pterygium has a high prevalence - for example, Australia, India, Japan, and Taiwan suggest that pterygium surgery is a common predisposing cause of infectious scleral ulcers. The poor prognosis of infectious scleral ulcers has been emphasised, ${ }^{68} 10$ with frequent reports of loss of the involved eye. In our series, we report more satisfactory results after aggressive management.

\section{Patients and methods}

The records of patients with culture proved or presumed infectious scleral ulcer from July
1989 to June 1994 were reviewed. Scleral extension of corneal infection, bleb related scleral ulceration and scleral inflammation resulting from underlying connective tissue disorder were excluded. Those cases with scleromalasia or poor epithelialisation of conjunctiva after pterygium excision were also excluded from our series. A total of 30 patients were studied. All of the cases had deep scleral erosion and melting with discharge or subconjunctival abscess with inflammatory reaction. Information including patient's age, onset and course of disease, pathogenic organism, clinical presentations, methods of diagnosis and treatment, and outcome were recorded.

\section{Results}

We collected 30 eyes of 30 patients ( 13 males, 17 females) of infectious or presumed infectious scleral ulcer, all with history of pterygium excision. The patients were aged 48 to 86 (mean age 64.3) years at presentation. Because all of the operations had been performed elsewhere, the characteristics of pterygium and surgical procedures were not available in our study. According to the description of patients, two cases received $\beta$ irradiation after pterygium removal, and the use of topical mitomycin $\mathrm{C}$, thiotepa, or radiation as an adjuvant could not be identified in the other 28 cases. The interval between pterygium excision and the onset of scleral ulcer varied from 2 weeks to over 20 years. Three cases (cases 19, 21, 22) had suffered since the first postoperative day, but 10 cases $(33.3 \%)$ had not developed ulcers until 10 years later.

Of the 30 patients, 10 were accompanied by corneal involvement, and four (cases 9, 13, 16, 19) were complicated by scleral perforation. Endophthalmitis was found in case 2. Posterior synechiae and/or pupil distortion were noted in 13 cases $(43.3 \%)$. Subconjunctival abscess was noted in 16 cases (53.3\%) under biomicroscopic examination during debridement surgery. Most of the subconjunctival abscesses did not connect to main lesion which we have classified as satellite lesions. Secondary glaucoma was a complication in eight cases and cataract in six.

The admission period varied from 3 to 98 (mean 32.5) days. Readmission was noted in eight cases because of a complicated course. All except one (case 11) had aerobic, anaerobic, and fungal cultures from the scleral scrapes on admission and biopsies during the surgical debridement. There were 17 cases $(56.7 \%)$ with positive results, all of which were Pseudomonas aeruginosa. Of the 17 patients, 

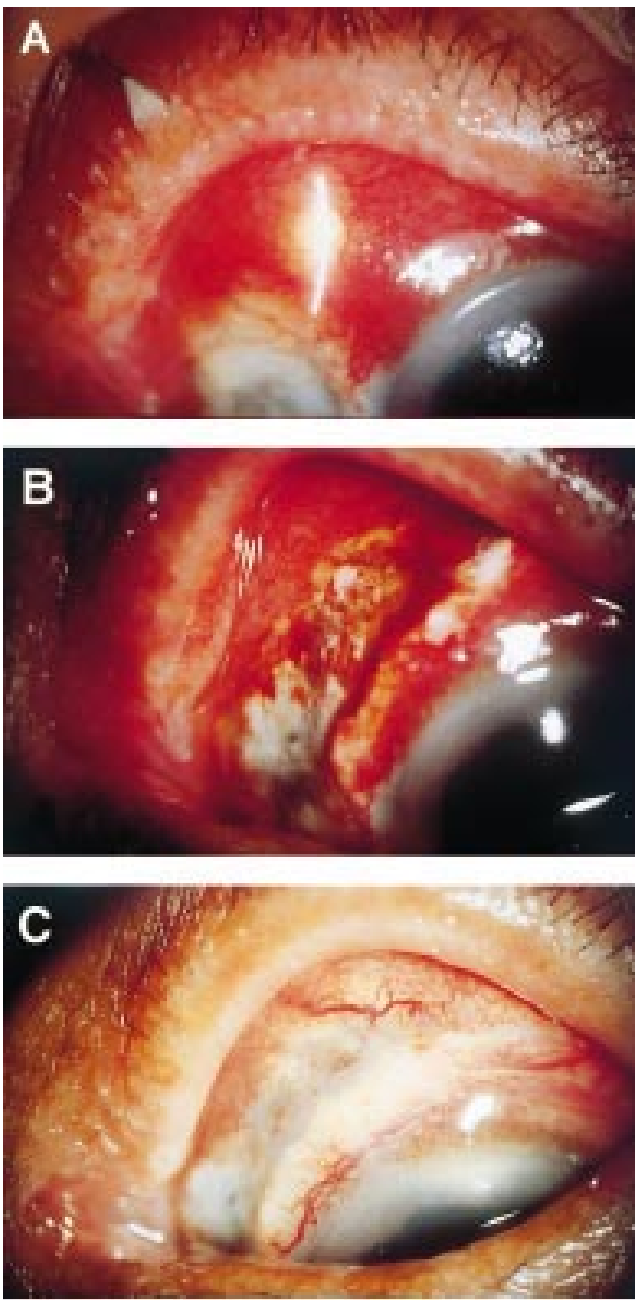

Figure 1 (A) The scleral ulceration was located at 9 $o$ 'clock position. Severe congestion and subconjunctival abscess were noted at 10 o'clock position under the biomicroscope. (B) After the surgical debridement, the scleral wound was left open. In comparison with $(A)$ the involved area was more extensive. (C) Ten days later, the debrided area was healing.

three had combined infections. Staphylococcus epidermidis was cultured in case 4, and Serratia marcescens was grown in case 22 . In addition, case 30 was complicated by fungal infection (Cladosporium).

Of the 12 cases which showed negative results after repetitive cultures, Gram stained, $\mathrm{KOH}$ stained, and acid fast stained scrapings of the ulcer were done in five. Gram stained scrapings showed many Gram positive cocci in case 21, and Gram negative bacilli in case 23. Atypical mycobacteria were disclosed on the acid fast stained scraping in case 24 .

The medical managements included topical eyedrops, subconjunctival injection of antibiotic, systemic antibiotic, and local irrigation of antibiotic or normal saline. Selection of antibiotics was based on the drug sensitivity tests when available. Since Pseudomonas was the most common pathogen, amikacin was most commonly selected. In consideration of superimposed infection, piperacillin was added to the treatment. Amikacin topical eyedrops were used alone in six cases, and 21 cases had received amikacin and piperacillin eyedrops at
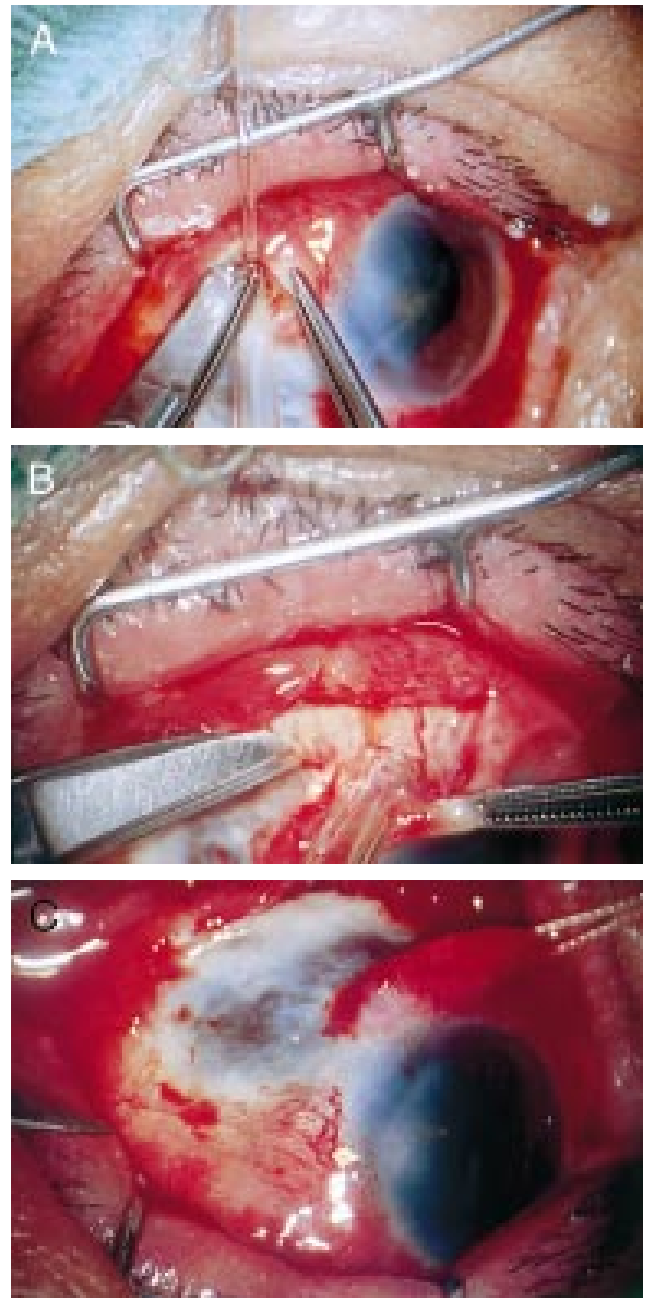

Figure 2 (A) During the surgical debridement, a tunnel lesion was detected with spring scissors easily entering intrastromal space. (B) Removal of the necrotic scleral tissue with spring scissors under continuous irrigation and aspiration. (C) The area involved was much larger than the visible lesion before debridement.

the same time. If the area of scleral ulceration became more extensive under medical treatment or subconjunctival abscess was suspected, surgical debridement was performed to remove the necrotic tissue and to expose the ulceration. Of 26 cases receiving surgical debridement, $10(33.3 \%)$ received debridement only once, while repetitive debridement was necessary in the remaining 16 .

During the surgical debridement the area actually involved was generally much larger than the visible lesion under biomicroscope view (Fig 1). Case 28 may be taken as an example. In spite of the visible lesion limited to 45 degrees of sclera, 360 degrees scleral involvement was noticed during the debridement. Subconjunctival abscess and intrascleral spreading, (which we have termed a 'tunnel lesion') were noted where apparently healthy conjunctiva and sclera were undermined (Fig 2). In some cases, the conjunctival flap was closed completely after debridement. Unfortunately, recurrence of multiple satellite subconjunctival abscesses was noted under the closed conjunctiva. Twelve cases underwent debridement twice or more times because of recurrent 
Table 1 Clinical manifestations of the cases of infectious scleral ulceration

\begin{tabular}{|c|c|c|c|c|c|c|c|}
\hline No & $\begin{array}{l}\text { Age } \\
\text { (years) }\end{array}$ & Sex & $\begin{array}{l}\text { Latent } \\
\text { period }\end{array}$ & $\begin{array}{l}\text { Admission } \\
\text { times/period } \\
\text { (days) }\end{array}$ & Pathogen & $\begin{array}{l}\text { Debride/graft } \\
\text { times }\end{array}$ & Remarks \\
\hline 1 & 70 & $\mathrm{~F}$ & $>10$ years & $1 / 7$ & NG & enucleation & post synechiae, cornea involved, SCA \\
\hline 2 & 69 & M & 4 years & $1 / 50$ & $\mathrm{~Pa}$ & $4 /$ conj+sclera & $\begin{array}{l}\text { calcified plaque, endophthalmitis, } \\
\text { post synechiae, glaucoma, SCA }\end{array}$ \\
\hline 3 & 48 & M & $>7$ years & $2 / 17$ & NG & $2 /$ conj+sclera & SCA \\
\hline 4 & 52 & $\mathrm{~F}$ & $>3$ years & $1 / 29$ & $\begin{array}{l}\mathrm{Pa} \text { and } S \\
\text { epidermidis }\end{array}$ & $1 /$ conj+sclera & staphyloma \\
\hline 5 & 69 & $\mathrm{~F}$ & $>3$ years & $2 / 48$ & $\mathrm{~Pa}$ & $1 /$ sclera & $\begin{array}{l}{ }^{\star} \text { radiation post synechiae, glaucoma, } \\
\text { SCA, hyphaema }\end{array}$ \\
\hline 6 & 85 & $\mathrm{~F}$ & NA & $1 / 27$ & $\mathrm{~Pa}$ & $2 /$ conj+sclera & post synechiae, cataract, SCA \\
\hline 7 & 60 & $\mathrm{~F}$ & 15 years & $1 / 24$ & $\mathrm{~Pa}$ & $3 /$ conj + sclera & post synechiae, cataract, SCA \\
\hline 8 & 59 & $\mathrm{~F}$ & 2 years & $1 / 40$ & & 4/conj+sclera & vitrous hazy, calcified plaque, SCA \\
\hline 9 & 50 & $\mathrm{~F}$ & 5 years & $1 / 3$ & NG & $1 /$ conj & calcified plaque \\
\hline 10 & 69 & M & $>6$ years & $4 / 22$ & NG & $3 /$ conj+sclera & perforation, cataract, post synechiae \\
\hline 11 & 12 & $\mathrm{~F}$ & $>10$ years & $1 / 8$ & NG & - & $\begin{array}{l}\text { post synechiae, SCA, cataract, cornea } \\
\text { involved, glaucoma }\end{array}$ \\
\hline 12 & 73 & $\mathrm{~F}$ & $>6$ years & $3 / 69$ & $\mathrm{~Pa}$ & $4 /$ conj & post synechiae, SCA, calcified plaque \\
\hline 13 & 84 & $\mathrm{~F}$ & $>10$ years & $1 / 38$ & $\mathrm{~Pa}$ & $2 /-$ & $\begin{array}{l}\text { post synechiae, SCA, perforation, } \\
\text { cornea involved, hyphaema }\end{array}$ \\
\hline 14 & 51 & M & 3 months & $2 / 13$ & NG & $2 /$ conj & \\
\hline 15 & 54 & M & 3 months & $1 / 20$ & $\mathrm{~Pa}$ & $1 /-$ & glaucoma, SCA \\
\hline 16 & 66 & M & $>10$ years & $1 / 68$ & NG & $2 /-$ & $\begin{array}{l}\text { perforation, staphyloma, post } \\
\text { synechiae }\end{array}$ \\
\hline 17 & 56 & $\mathrm{~F}$ & $>4$ years & $1 / 38$ & NG & $4 /-$ & post synechiae \\
\hline 18 & 67 & $\mathrm{~F}$ & $>10$ years & $1 / 27$ & $\mathrm{~Pa}$ & $2 /-$ & staphyloma \\
\hline 19 & 66 & $\mathrm{~F}$ & 2 months & $1 / 20$ & $\mathrm{~Pa}$ & $1 /-$ & perforation, cloudy vitreous, SCA \\
\hline 20 & 61 & M & 2 weeks & $1 / 19$ & NG & - & cornea involved \\
\hline 21 & 52 & M & $>20$ days & $1 / 5$ & NG & $1 /$ conj & \\
\hline 22 & 64 & M & 3 months & $2 / 98$ & $\begin{array}{l}\mathrm{Pa} \text { and } S \\
\text { marcescens }\end{array}$ & $5 /-$ & cornea involved, glaucoma \\
\hline 23 & 67 & M & 2 years & $1 / 8$ & NG & $1 /-$ & calcified plaque \\
\hline 24 & 71 & M & 4 months & $1 / 23$ & NG & $1 /-$ & cornea involved, SCA, glaucoma \\
\hline 25 & 73 & M & 1 month & $1 / 11$ & NG & $1 /-$ & cornea epithelial defect \\
\hline 26 & 62 & $\mathrm{~F}$ & 2 years & $1 / 60$ & $\mathrm{~Pa}$ & $3 /-$ & glaucoma, cloudy vitreous, SCA \\
\hline 27 & 76 & $\mathrm{~F}$ & $>10$ years & $2 / 79$ & $\mathrm{~Pa}$ & $4 /-$ & $\begin{array}{l}\text { vitreous haemorrhage, SCA, } \\
\text { glaucoma, calcified plaque, lens } \\
\text { swelling, post synechiae }\end{array}$ \\
\hline 28 & 55 & $\mathrm{~F}$ & $>20$ years & $2 / 61$ & $\mathrm{~Pa}$ & $1 /-$ & $\begin{array}{l}{ }^{\star} \text { radiation corneal epithelial defect, } \\
\text { SCA, post synechiae, cataract }\end{array}$ \\
\hline 29 & 60 & $\mathrm{~F}$ & $>10$ years & $1 / 25$ & $\mathrm{~Pa}$ & $1 /-$ & \\
\hline 30 & 61 & M & $>10$ years & $1 / 18$ & $\begin{array}{l}\mathrm{Pa} \text { and } \\
\text { Cladosporium }\end{array}$ & - & $\begin{array}{l}\text { cornea involved, descematocele } \\
\text { glaucoma, staphyloma }\end{array}$ \\
\hline
\end{tabular}

$\mathrm{Pa}=$ Pseudomonas aeruginos $;$, SCA = subconjunctival abscess; NA = not available; $\mathrm{NG}=$ no growth.

* Two cases had received $\beta$ irradiation as an adjuvant of pterygium surgery.

(1) The order of the cases was arranged by the presentation time.

(2) The age represented the age when the ulceration developed.

(3) The duration between pterygium surgery and the onset of scleral ulceration was recorded as latent period.

(4) The admission times recorded the recurrent or relapsed frequency of scleral ulceration.

(5) The admission days meant the sum of the hospitalised days.

abscesses. Judging from experience of several cases, we now leave the bare sclera alone rather than close the conjunctival flap after the necrotic tissue has been removed. We believe that residual micro-organisms behind the early reattached conjunctiva may cause the recurrence of infection and prolong the course despite daily local irrigation of antibiotic. Scleral transplantation and conjunctival autotransplantation were performed in seven cases. Conjunctival flap only and scleral graft only were performed in four cases and one case, respectively. All of the eyeballs involved were salvaged except in case 1 , who had undergone enucleation at another clinic after she asked for discharge from our institution.

\section{Discussion}

Post-pterygium excision infectious scleral ulcers have usually been reported following $\beta$ irradiation, ${ }^{16-19}$ use of mitomycin $C,{ }^{19-24}$ and excessive cauterisation. In our experience, pterygium excision alone can also induce this condition. Vascular deprivation ${ }^{14} 25$ has been suggested as the cause, but since the sclera is an avascular tissue with very little nutritional demand, ischaemia alone would not seem to be a main factor for this process. As David's work has demonstrated, ${ }^{25}$ when silicone was placed between episcleral plexuses and choroid and sclera to deprive both sides of the blood supply to sclera, it did not induce any scleral change, which meant ischaemia alone would not induce scleral degeneration.

Enzymatic degradation ${ }^{26} 27$ may play some part in the massive invasion of scleral ulcer that developed immediately after pterygium excision. Tissue destruction during the pterygium operation and prolonged exposure of the bare sclera may stimulate enzymatic degradation by collagenases. Host derived proteoglycolytic enzymes may all be extensively involved. After the initial lysis, a defected epithelial defence mechanism can predispose to invasion by micro-organisms, and tissue lytic enzymes delivered from micro-organism-for example, protease from Pseudomonas, aggravate the process. Invading polymorphonuclear leucocytes and degenerating cells have all been proposed as possible sources of the various hydrolytic enzymes. ${ }^{10}$

Early unrecognised infectious scleral ulcer may be misdiagnosed as scleritis and treated with steroid. This can decrease the ocular 
defence mechanism and increase the lytic enzyme activity, ${ }^{27-29}$ and may also be a predisposing factor.

It is unusual for an operative site to be infected after a long and silent postoperative period without adjuvant management. For those cases, the trigger mechanism is still unknown for the development of scleral ulcer after a long latent period. But it is clear that necrotising scleritis can be activated after surgery. ${ }^{30}$ The latent period between surgery and the onset of scleritis can be as long as 40 years. ${ }^{30}$ The situation is similar to the late onset of infectious scleral ulcer over 20 years after operation. The mechanism which induces the necrotising scleritis may be a prodromal factor to induce the infectious scleral ulcer. It can be postulated that after initiation of the necrotising scleritis, the micro-organism invaded and caused the late onset post-pterygium excision infectious scleral ulcer.

Most of the previous reports of infectious scleral ulcer pointed out that a very poor prognosis would result when micro-organisms invaded the sclera, ${ }^{6}{ }^{810}$ but this is not true in our cases. After managing a few cases, we soon recognised that, owing to the structure of dense collagen fibres and avascularity of sclera, antibiotic penetration of sclera is very poor, even through eyedrops, subconjunctival injection, or systemic use. We feel that debridement is mandatory in such cases. Removing the infected necrotic tissue with an open lesion is the only way to improve antibiotic treatment. A slender lesion extending only into the deep layer of sclera with the superficial overlying infection free sclera and conjunctiva was found during debridement; we call it 'tunnel lesion'. Such lesions need careful opening and checking during debridement. A similar lesion has been reported by Raber et $a l^{10}$ in their histopathological findings in cases of scleral ulcer extending from Pseudomonas corneal ulcer which was enucleated after the failure of treatment. They pointed out that medication was useless after bacterial invasion of sclera. Because Raber et al had not identified such lesions earlier, the medical management was poor. In our experience in such cases, early debridement can save the eye. After debridement, irrigating the wound with or without antibiotic daily helped to clear the lesion. Irrigation removed the necrotic tissue, microorganisms, and the proteolytic enzyme which usually accumulated in the deep furrow of the lesion after debridement.

We believe that early debridement and an open debrided wound are mandatory in the management of infectious scleral ulcer, no matter what the apparent size of the lesion. We emphasise the combination of medical management including systemic and topical antibiotics, subconjunctival injection of antibiotic at both ends of the scleral lesion, and wound irrigation first with antibiotic solution once or twice daily and then lactate Ringer or normal saline after improvement.
This study was conducted at Kaohsiung Medical College, Kaohsiung, Taiwan, ROC.

1 Ramzi H, Maite S, Michael BR. Six cases of scleritis associated with systemic infection. $A m \quad \mathcal{O}$ Ophthalmol ated with system

2 Schonherr U, Naumann GOH, Lang GK, Bialasiewicz AA. Sclerokeratitis by Mycobacterium marinum. Am $\mathcal{f}$ Ophthalmol 1989;108:607-8.

3 Glassroth J, Robins AG, Snider DE Jr. Tuberculosis in 1980s. N Engl F Med 1980;302:1441-50.

4 Tamesis RR, Foster CS. Ocular syphilis. Ophthalmology 1990;97:1281-7.

5 Wilhelmus KR, Yokoyama CM. Syphilitic episcleritis and scleritis. Am f Ophthalmol 1987;104:595-7.

6 Reynolds MG, Alfonso E. Infectious scleritis and keratoscleritis: management and outcome. Am f Ophthalmol 1991;112:543-7.

7 Tarr KH, Constable IJ. Pseudomonas endophthalmitis associated with scleral necrosis. Br F Ophthalmol 1980;64: $676-9$.

8 Alfonso E, Kenyon KR, Ormerod LD, Stevens R, Wagoner $\mathrm{MD}$, Albert DM. Pseudomonas corneoscleritis. Am f Ophthalmol 1987;103:90-8

9 Codere F, Brownstein S, Jackson WB. Pseudomonas aeruginosa scleritis. Am f Ophthalmol 1981;91:706-10.

10 Raber IM, Laibson PR, Kurz GH, Bernardino VB. Pseudomonas corneoscleral ulcers. Am f Ophthalmol 1981; 92:353-63.

11 James CF, Johann C, Franklin PK. Bacterial scleral abscesses after retinal buckling operations. Ophthalmology 1987;94:1148-54

12 Lindsey PS, Pierce H, Welch RB. Removal of scleral buckling elements: causes and complications. Arch Ophthalmol 1983;101:570-3.

13 Pope J, Sternberg P, McLane NJ, Potts DW, Stulting RD. Mycobacterium chelonei scleral abscess after removal of a scleral buckle. Am $\mathcal{F}$ Ophthalmol 1989;107:557-8.

14 David LO, James EP, John GM, Mark LM. Scleral flap necrosis and infectious endophthalmitis after cataract surgery with a scleral tunnel incision. Ophthalmology 1993; 100:159-63.

15 Stonecipher KG, Parmley VC, Jensen H, Rowsey JJ. Infectious endophthalmitis following sutureless cataract surgery. Arch Ophthalmol 1991;109:1562-3.

16 Fraser DM, Lawrence WH, Bruce K, Christopher B. Recurrence rate and complications after beta irradiation for pterygia. Ophthalmology 1991;98:1776-81.

17 Anthony PM, Geoffrey JC, Ian LM, Ian JC. Severe corneoscleral infection. A complication of beta irradiation scleral necrosis following pterygium excision. Arch Ophthalmol 1993;111:947-51.

18 Anthony PM, Geoffrey JC, Ian LM, Ian JC. Bilateral streptococcal corneoscleritis complicating beta irradiation induced scleral necrosis. Br f Ophthalmol 1993;77:251-2.

19 Tarr KH, Constable IJ. Late complications of pterygium treatment. Br f Ophthalmol 1980;64:496-505.

20 Farrell PLR, Smith RE. Bacterial corneoscleritis complicating pterygium excision. Am f Ophthalmol 1989;107:515-7.

21 Roy SR, Roswell RP, Raymond MS, Stephen F, Neil FM, Samnel S, et al. Serious complications of topical mitomycin-C after pterygium surgery. Ophthalmology 1992;99:1647-54

22 Fukamachi Y, Hikita N. Ocular complication following pterygium operation and instillation of mitomycin C. Folia Ophthalmol fpn 1981;32:197-201.

23 Yamanouchi U, Takaku I, Tsuda N, Kajiwara Y, Mine M, Ueno Y, et al. Scleromalacia presumably due to mitomycin $\mathrm{C}$ instillation after pterygium excision. Fpn $\mathcal{f}$ Clin Ophthalmol 1979;33:139-44.

24 Singh G. Postoperative instillation of low-dose mitomycin C in the treatment of primary pterygium. Am $\mathcal{F}$ Ophthalmol 1989;107:570-1.

25 David S. Necrogranulomatous scleritis-effects on the sclera of vascular deprivation. Br f Ophthalmol 1968;52: 453-60

26 Gordon JM, Bauer EA, Eisen AZ. Collagenase in human cornea. Immunologic localization. Arch Ophthalmol 1980; 98:341-5.

27 Kreger AS, Gray LD. Purification of Pseudomonas aeruginosa protease and microscopic characterization of pseudomonal protease-induced rabbit corneal damage. Infect Immun 1978;19:630-48.

28 Brown SI, Weller CA, Vidrich AM. Effect of corticosteroids on corneal collagenase of rabbits. Am $\mathcal{f}$ Ophthalmol 1970;70:744-7.

29 Harbin T. Recurrence of a corneal Pseudomonas infection after topical steroid therapy. Report of a case. $A m \mathcal{F}$ Ophthalmol 1964; 58:670.

30 O'Donoghue E, Lightman S, Tuft S, Watson S. Surgically induced necrotising sclerokeratitis-precipitating factors and response to treatment. Br $\mathcal{F}$ Ophthalmol 1992;76:1721 . 